\title{
Does the Analysis of Altman Z-Score Model, Zmijewski Model, and Springate Model Impact the Financial Distress?
}

\section{Study on Pharmaceutical Companies Listed on the Indonesian Stock Exchange Period 2011-2017}

\author{
Santi Damayanti ${ }^{1, *}$ \\ ${ }^{1}$ Sekolah Tinggi Ilmu Ekonomi Indonesia Membangun(INABA) \\ *Corresponding author.Email: santidama@yahoo.co.id
}

\begin{abstract}
Financial distress has a significant impact on the company that will potentially suffer losses, but also investors, creditors, and communities. There are some tools used to detect bankruptcy, namely Altman Z-Score, Zmijewski, and Springate model. This study uses descriptive and verification methodology. The data used are secondary. The data were collected through library research and documentation retrieval from IDX official website. Purposive sampling methodology was employed to select the sample, and it obtained data from eight pharmaceutical companies. The results showed that the mean of Altman Z-Score was 2.99\%, the mean of the Zmijewski model was 3.05\%, and the mean of Springate was $1.94 \%$. Moreover, the mean of financial distress was $209.90 \%$. Based on the coefficient of determinations results of 0.198, the results showed that the analysis of Altman Z-Score, Zmijewski, and Springate concerning financial distress had a simultaneous impact of $19.8 \%$. The remaining $80.2 \%$ was influenced by other variables outside the regression models, including high raw material expenses, poor financial planning, and poor cash flow management.
\end{abstract}

Keywords: Altman Z-Score Model Analysis, Zmijewski Model Analysis, Springate Model Analysis, Financial Distress.

\section{INTRODUCTION}

The pharmaceutical sector is related to the supply of medicines and medical devices most needed by the community. The bankruptcy of a pharmaceutical company will disturb the drug supply chain. It is particularly needed by patients who were prescribed drugs from the Social Security Administrative Body for Health (BPJS Kesehatan) services. Therefore, this study aimed to analyze financial distress in pharmaceutical companies listed on the Indonesia Stock Exchange in 2011-2017 using the Altman Z-Score, Zmijewski, and Springate models both partially and simultaneously.

Financial distress is a problematic financial condition of a company that experiences a crisis, unhealthy, and occurs before bankruptcy [1], [2], [3].; Nasution, 2015; Indri 2012:103). Financial distress occurs when the company fails or is no longer capable of fulfilling the debtor's obligation due to a lack of funds to run its business.This template, modified in MS Word 2007 and saved as a "Word 97-2003 Document" for the PC, provides authors with most of the formatting specifications needed for preparing electronic versions of their papers. All standard paper components have been specified for three reasons: (1) ease of use when formatting individual papers, (2) automatic compliance to electronic requirements that facilitate the concurrent or later production of electronic products, and (3) conformity of style throughout a conference proceeding. Margins, column widths, line spacing, and type styles are built-in; examples of the type styles are provided throughout this document and are identified in italic type, within parentheses, following the example. Some components, such as multi-leveled equations, graphics, and tables are not prescribed, although the various table text styles are provided. The formatter will need to create these components, incorporating the applicable criteria that follow. 


\section{METHODS}

This study employs Altman Z-Score, Zmijewski, and Springate analysis concerning financial distress. The three models were used to predict the company's sustainability by combining several general financial ratios by giving them different values between the ratios. Meanwhile, the cut-off value of each model is as follows: (1) Altman Z-Score uses a cut-off value of 2.99 and 18.1; (2) Zmijewski uses a cut-off value of 0; (3) Springate uses a cut off value of 0.862 .

This study employed a quantitative methodology with a descriptive verification approach. The secondary quantitative data were used in this study. The data were in the form of the publicly listed pharmaceutical companies' financial reports on the Indonesia Stock Exchange in 2011-2017. The data were retrieved from www.IDX.co.id. This study collected the data through library research and documentation retrieval by examining financial reports published by the pharmaceutical companies in 2011-2017.

\section{RESULTS AND DISCUSSION}

This study showed that the mean of Altman Z-Score, Zmijewski, Springate analysis were consecutively $2.99 \%, 3.05 \%$, and $1.94 \%$. Besides, the mean of financial distress was $209.90 \%$. Meanwhile, the results of the study on the impact of partial variables showed that (1) Altman Z-Score has no impact on financial distress because the value of tcount $<$ ttable was $(-0.383<2.006)$, it can be concluded that Ha was rejected and Ho was accepted. (2) Zmijewski's model impacted financial distress because the value of tcount $>$ ttable was $(2.056>2.006)$. It can be concluded that Ho was rejected and Ha was accepted. (3) The Springate model impacted financial distress because the value of tcount $>$ ttable was $(-2.793>-2.006)$. It can be concluded that Ho was rejected and Ha was accepted. Based on the results of the coefficient of determination of 0.198, the Altman Z-Score, Zmijewski, and Springate analysis gave a simultaneous effect on financial distress of as much as $19.8 \%$. In comparison, the remaining $80.2 \%$ was influenced by other variables outside the regression model, including raw material expenses, poor financial planning, and poor cash flow management.

Verification analysis was used to investigate the hypothesis on Altman Z-Score, Zmijewski, Springate variables towards financial distress. It was proofed by Statistics 22.0 and could show wheter the hypothesis is accepted or rejected.

The followings are the results of verification analysis:

\subsection{The influence of Altman Z-Score on financial distress.}

Based on the partial $t$ test result, the value of tcount $0.383<$ ttable -2.006 with the significance of 0.704 >
0.05. It means that $\mathrm{H} 0$, stating that Altman Z-Score did not affect financial distress, was accepted.

\subsection{The impact of Zmijewski variables on Financial distress}

Based on the partial test results (t test) where the tcount $2.056>$ ttable 2.006 with a significant value of $0.045<0.05$, it means accepting the $\mathrm{H} 2$ hypothesis stating there is an impact of Zmijewski on financial distress [4].

\subsection{The impact of Springate variables on financial distress}

Based on the partial test results ( $t$ test) where the value of tcount $-2.793>$ ttable -2.006 with a significant value of $0.007<0.05$, it means accepting the $\mathrm{H} 3$ hypothesis stating that there is an impact of Springate on financial distress. The study results are in line with a reference [5].

\subsection{The impact of Altman Z-Score and Zmijewski variables on financial distress simultaneously}

The Altman Z-Score, Zmijewski, Springate variables simultaneously significantly impact financial distress in 8 pharmaceutical companies listed on the IDX in 20112017. It is proved by Fcount $4.287>$ Ftable 2.78 and a significant value of $0.009<0.05$. Meanwhile, the correlation coefficient $(\mathrm{R})$ of 0.445 means the relationship between the independent and dependent variables has a moderate level of relationship. The coefficient of determination (R2) of 0.198 or $19.8 \%$ means that the Altman Z-Score, Zmijewski, and Springate variables provide a simultaneous impact of $19.8 \%$ on financial distress, while other variables outside the regression model influence $80.2 \%$.

\section{CONCLUSION}

Based on the results of the study and discussion, there are several conclusions drawn as follows:

Partially, it can be concluded that the analysis of Altman Z-Score does not have a significant impact on the financial distress of eight pharmaceutical companies listed on IDX in 2011-2017. The results of this study were not in line with the study conducted in reference [6]. On the other hand, Zmijewski and Springate's analysis affected financial distress significantly on eight pharmaceutical companies listed on the IDX in 20112017. These results were in line with previous studies [4], [5].

Simultaneously, the Altman Z-Score, Zmijewski, and Springate analysis significantly impacted the financial distress of eight pharmaceutical companies listed on the Indonesia Stock Exchange in 2011-2017. That analysis was simultaneously affected the financial distress by as 
much as $19.8 \%$, while the remaining $80.2 \%$ was influenced by other variables outside the regression model, including high raw material expenses, poor financial planning, and poor cash flow management.

\section{REFERENCES}

[1] H. D. Platt and M. B. Platt, "A note on the use of industry-relative ratios in bankruptcy prediction," Journal of Banking \& Finance, vol. 15, no. 6, pp. 1183-1194, 1991.

[2] P. Nasution, Pengaruh Likuiditas dan Profitabilitas Terhadap Finansial Distress pada Perusahaan Farmasi yang Terdaftar di Bursa Efek Indonesia Periode2010-2014. Palembang: Politeknik Negeri Sriwijaya, 2015.

[3] Indri. Pengaruh struktur Corporate governance dan Financial Indikator terhadap kondisi Financial Distress perusahaan manufaktur periode 2009- 2011. Jurnal Accounting Vol 2 no 2, 2012.
[4] F. Sondakh, P. Tommy, and M. Mangantar, Urrent Ratio, Debt to Equity Ratio, Return on Asset, Return on Equity Pengaruhnya Terhadap Harga Saham Pada Indeks Lq 45 Di Bei Periode 2010-2014, vol. 3. Jurnal EMBA: Jurnal Riset Ekonomi, Manajemen, Bisnis dan Akuntansi, 2015.

[5] N. M. E. D. Prihanthini and M. M. R. Sari, "Prediksi Kebangkrutan Dengan Model Grover, Altman ZScore, Springate Dan Zmijewski Pada Perusahaan Food And Beverage Di Bursa Efek Indonesia," EJurnal Akuntansi, vol. 5, no. 2, pp. 417-435, 2013.

[6] S. Yati and K. I. A. Patunrui, "Analisis Penilaian Financial Distress Menggunakan Model Altman (ZScore) Pada Perusahaan Farmasi Yang Terdaftar di Bursa Efek Indonesia Periode 2013-2015," Jurnal Akuntansi, Ekonomi dan Manajemen Bisnis, vol. 5, no. 1, pp. 55-71, 2017. 